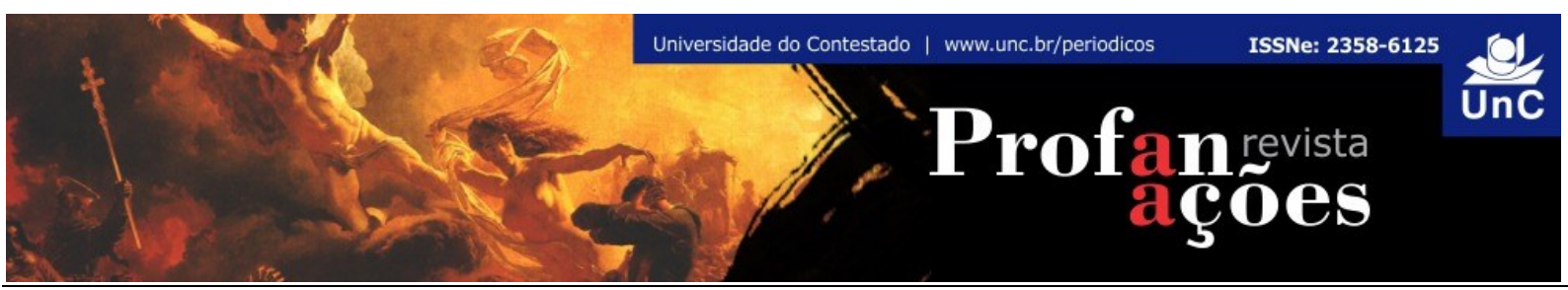

\title{
LAMENTO, A IMPOTÊNCIA DA LINGUAGEM
}

Diogo Cesar Nunes ${ }^{1}$

RESUMO: O presente artigo toma como ponto de partida reflexões realizadas por Giorgio Agamben acerca da pintura O esfolamento de Marsias, de Ticiano, para pôr em questão a relação entre a "inspiração" artística e o trabalho do pensamento crítico enquanto trabalho de luto. Assim, recorre a conexões entre os pensamentos de Agamben e de Benjamin, no intuito de tomar do filósofo alemão indicações sobre a "melancolia barroca" que permitam sustentar a hipótese de que o quadro de Ticiano, ao representar o próprio pintor como Midas buscando ouvir o "lamento" de Marsias, seja "exemplar" do luto que corresponde tanto ao trabalho do filósofo quanto ao do artista. Isso porque ambos tomariam como "objeto" aquilo que é irrepresentável ao olhar e impossível à palavra: a relação, sempre pendente, entre potência e impotência.

Palavras-chave: Lamento. Linguagem. Impotência. Criação artística. Luto.

\section{LAMENT, THE IMPOTENCE OF LANGUAGE}

ABSTRACT: This paper is based on Giorgio Agamben's reflections about Ticiano's painting Flaying of Marsyas, in order to question the relationship between artistic "inspiration" and the work of critical thinking as a work of mourning. Thus, it establishes connections between thoughts of Agamben and Benjamin, in order to take from the german philosopher indications on the "baroque melancholy" in order to assert that Ticiano's picture, by representing the painter himself as Midas seeking to hear the "lament" of Marsyas, is "exemplary" of the mourning that corresponds as much to the work of the philosopher as to the work of the artist. This is because both would take as an "object" that which is unrepresentable to the look and impossible to the word: the relationship, always hanging, between potency and impotence.

Keywords: Lament. Language. Impotence. Artistic creation. Mourning.

1Doutor em Psicologia Social, pela Universidade do Estado do Rio de Janeiro. Professor da UNIABEU
$\begin{aligned} & \text { Centro Universitário. UNIABEU Centro Universitário. Rio de Janeiro. Brasil. E-mail: } \\ & \text { diogodcns@gmail.com }\end{aligned}$ 
[...] o lamento é a expressão mais indiferenciada, mais impotente da

linguagem.

(Walter Benjamin)

1.

Em artigo recentemente publicado ${ }^{2}$, Giorgio Agamben propõe uma leitura da tela $O$ Esfolamento de Marsias, a última pintada por Ticiano, confrontando sua imagem a passagens do Paraíso, de Dante, e das Metamorfoses, de Ovídio. Certo que Ticiano tivera contato com os versos dantescos (publicados entre 1502 e 1568), que já no início invocam o sofrimento de Marsias como "uma metáfora da inspiração" (AGAMBEN, 2018, p. 15), Agamben propõe que sua "metáfora" diga respeito às artes e ao processo criativo, em geral, e não especificamente à música. Se Dante "transferiu" o tema da música à poesia, cumpriu a Ticiano, a partir de "suas inegáveis leituras da Comédia" (AGAMBEN, 2018, p. 15), dar-Ihe lugar na pintura.

Das várias narrativas sobre o esfolamento do sátiro, aquela que Agamben mobiliza para avançar na sua interpretação é a de Diodoro Sículo. Marsias desafia Apolo a uma competição musical, de modo que ao vencedor caberia o direito de infligir punição ao oponente. Após Marsias apresentar-se com a flauta, Apolo

[...] acompanha a cítara com o canto e quando Marsias protesta, objetando que a disputa era 'de arte mas não de voz' (artis at non vocis), [Apolo] responde que não usou nada mais do que aquilo que o adversário havia feito 'ao soprar a flauta' (cum tibias inflasset) (AGAMBEN, 2018, p. 13).

Na sequência do artigo, Agamben aciona a Política, de Aristóteles, para falar da inferioridade "moral" da flauta, pois que "impede o uso da palavra (kolyein to logo chresthai ten aulesin)", chegando a um tema que é como que central nas suas reflexões - lançado e desenvolvido em outros trabalhos por caminhos diferentes - $e$ que no conflito entre o sátiro e Apolo é apresentado como "a superioridade do logos sobre a música instrumental e a da racionalidade apolínea sobre o orgiasmo semihumano do sátiro" (AGAMBEN, 2018, p. 14).

2 Publicado originalmente, em 2017, na revista italiana De pictura, o artigo foi traduzido por Vinícius N. Honesko e publicado na revista Diálogos Mediterrânicos (AGAMBEN, 2018). 
O conflito encenado entre Apolo e Marsias, entre voz e som (mais especificamente, entre canto e sopro), dá lugar àquele que, para Agamben, concentra "o problema" tanto da metafísica quanto da política: a passagem do som à voz, ou do ruído (phoné) à palavra (logos), não é guiada pela necessidade ("há de ser"), mas pela contingência ("pode ser"), e, assim, situa aquela que seria a condição do "ser do logos", a potência. A considerar que a potência é, também, e necessariamente, impotência (a ausência da impotência, do "pode não", ou do "pode ser que não", na potência, faria dela uma necessidade) ${ }^{3}$, a palavra não se realiza por completo senão mantendo um resíduo, por assim dizer, ou um "resto" do seu "outro" negado. Trata-se, neste "resto", de uma "zona obscura e dolorosa" (AGAMBEN, 2018, p. 15), que Ticiano teria deslocado "metaforicamente" para a pintura, como representante da "inspiração" artística. Assim, o "deslocamento metafórico" lido por Agamben não é somente da música (no mito) à poesia (em Dante) e, desta, à pintura, mas também da metafísica e da política às artes. O que Ticiano, autorretratado na tela como Midas, tem diante de si é a representação desta "zona obscura e dolorosa entre o inumano e o humano e entre o animal e o divino" (AGAMBEN, 2018, p. 15).

Avancemos esboçando uma leitura dialética do que nos oferece Agamben. sopro é como que um pressuposto da voz que esta, superando dialeticamente, conserva e transforma. Apolo, deus do sol e da razão, é por inteiro representado como humano: à imagem e semelhança, diríamos, do "ser do logos". A "superioridade" apolínea do logos, se compreendida como racionalidade, expõe sua bestialidade (sua "inumanidade") na punição dirigida a Marsias, como se o gesto da barbárie fosse o da tentativa de dissimular aquilo que, recalcado, retorna como violência projetiva4: a bestialidade da própria razão - signo maior do "humano" contra a bestialidade corpórea e musical do sátiro, meio humano e meio bode, cujo "sopro" é inferior à "voz", ainda que cantada, da razão. A "superioridade" da palavra, ou da voz, em relação ao ruído, ou ao sopro, encontraria na violência ao sátiro a

\footnotetext{
${ }^{3}$ Agamben enfatiza o conteúdo "impotente" da potência em diferentes trabalhos, sendo este não somente um tema, mas um pressuposto importante das suas reflexões. Para uma reflexão mais detalhada do assunto, sugere-se o livro A potência do pensamento, publicado no Brasil em 2015, pela editora Autêntica, dez anos após o original em italiano, que reúne ensaios e conferências que datam do início dos anos 1980 até meados da década passada (AGAMBEN, 2015).

${ }^{4}$ Retoma-se, aqui, a tese presente na Dialética do Esclarecimento de que o Esclarecimento somente se apresenta - totalitariamente - como racional na medida em que recalca seu próprio caráter mítico e irracional (ADORNO; HORKHEIMER, 1985).
} 
expressão não da sua força, mas, ao contrário, da sua fraqueza: o não reconhecimento de que aquilo que a distingue do "outro" ela encontra em si mesma. Daí haver de recorrer justamente à tortura, signo talvez absoluto da crueldade e do que há de contrário à razão/linguagem, para se afirmar como "superior". Como se a emergência do diálogo (o que se dá através, dia, do logos) como instância "superior" (racional), somente pudesse acontecer sob o regime da violência, ou, mais especificamente, sob um regime de recalque desta violência. Marsias é duplo - meio homem, meio animal -, e tal contradição a "força" apolínea não parece capaz de suportar: a duplicidade bestial do sátiro é um espelho demasiado incômodo que a superioridade do logos deve suprimir, ainda que, para isso, deva recorrer à mais pura expressão da animalidade.

Que seja em relação a tal cena que se ponha Ticiano, é o que constitui a matéria de análise de Agamben: o artista observa, algo contemplativo, a animalidade da razão contra a alteridade que a habita, suportada na imagem do "outro" meiohumano. Se o que Ticiano/Midas tem diante de si é a própria cena da "inspiração artística", seria porque o gesto da criação não derivaria de um sobressalto do logos em relação ao mero som, tampouco de um "sopro" indiferente ao logos, mas daquela contradição insuperável - a despeito da violência e do recalque - que pode ser chamada pela expressão im/potência.

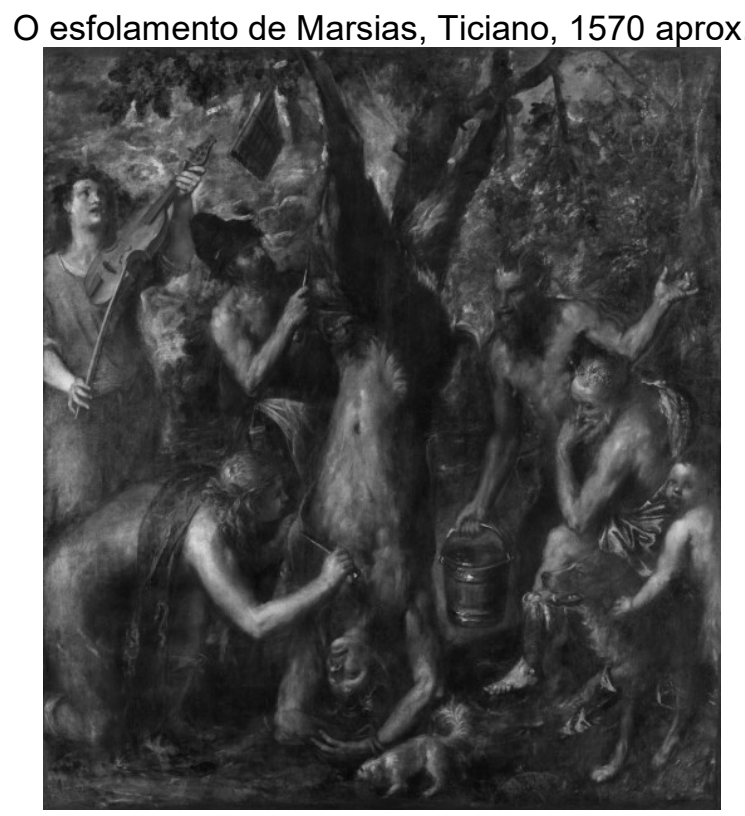




\section{2.}

Se Ticiano representa a si mesmo como Midas, que ganhou orelhas de burro justamente por não concordar com a superioridade de Apolo, podemos supor seus sentimentos em relação ao destino do sátiro. Mas o que é possível observar na tela não é exatamente uma expressão de consternação na face de Midas, mas de atenção. Seu olhar se dirige ao de Marsias, que se lança ao do espectador. Todos, contudo, impotentes diante da cena do esfolamento. O que se passa ali, diz Agamben (2018, p. 15), "não pode ser expresso em palavras". Mas há palavras, as ditas por Marsias em suplício, que Agamben ressalta como sendo um "lamento". E assim o filósofo termina seu texto, dizendo que "é a tal lamento - não à música divina, não à palavra humana - que Midas dá ouvidos com suas orelhas de burro; é esse débil, incessante e ilegível lamento que está em questão na última pintura de Ticiano" (AGAMBEN, 2018, p. 15).

Há palavras, mas o que se passa não pode ser expresso em palavras. Expressão do que, em palavras, não pode nelas ser expresso é o "lamento". Agamben, ao encerrar seu texto, deixa ao leitor uma pista que remete a Benjamin, mais especificamente ao ensaio Sobre a linguagem em geral e sobre a linguagem do homem: o lamento, escreveu Benjamin (2011, p. 70), "é a expressão mais indiferenciada, mais impotente da linguagem". Outra pista disposta pelo caminho é a do gesto de Midas representado na tela, "a pose saturnina do melancólico" - que, curiosamente, e sem dar mais detalhes, Agamben chega a associar ao autorretrato de Michelangelo, como São Bartolomeu, no afresco O Juízo Final.

A "pose saturnina" de Midas corresponde à sua ação, ou à sua não ação: observar a cena da impossibilidade, ouvir o que, na palavra, não tem lugar na palavra. A cabeça sustentada pela palma da mão - que, como Atlas, parece ter o peso de um mundo -, com o tronco arqueado para frente, fazendo encontrarem-se cotovelo e joelho (desde Rodin, posição exemplar do pensador), não difere daquela que, para Benjamin, melhor representa a melancolia barroca: a do anjo da gravura Melancolia I, de Albrecht Dürer. Na gravura, o anjo observa os "instrumentos da vida ativa" com os quais o renascentista "investiga o universo", vendo neles as ruínas do saber e estas como "fonte de uma sabedoria misteriosa". Numa "contemplação absorta", o melancólico barroco está enlutado pela "despersonalização cartesiana", 
pela "desvitalização dos afetos", à beira da "queda num abismo sem fundo" (BENJAMIN, 2013, p. 147).

Como anotou Maria João Cantinho (2015, p. 61-62), o "homem barroco" de Benjamin está no limiar entre a destruição e a salvação: "reconhecendo a sua impotência face ao desenrolar dos acontecimentos, [o 'homem barroco'] adere ao mundo" encontrando-se "imerso na ordem da natureza, no turbilhão da sua história, 'escravo' das leis naturais e 'escravo' da temporalidade aniquiladora e irreversível”. Ele quer "salvar" o mundo e as coisas dos seus destinos trágicos, da destruição total, mas, tal qual Midas diante do sofrimento de Marsias, é incapaz de fazê-lo, pois é preciso, todavia, "salvar" o próprio conhecimento da catástrofe do destino.

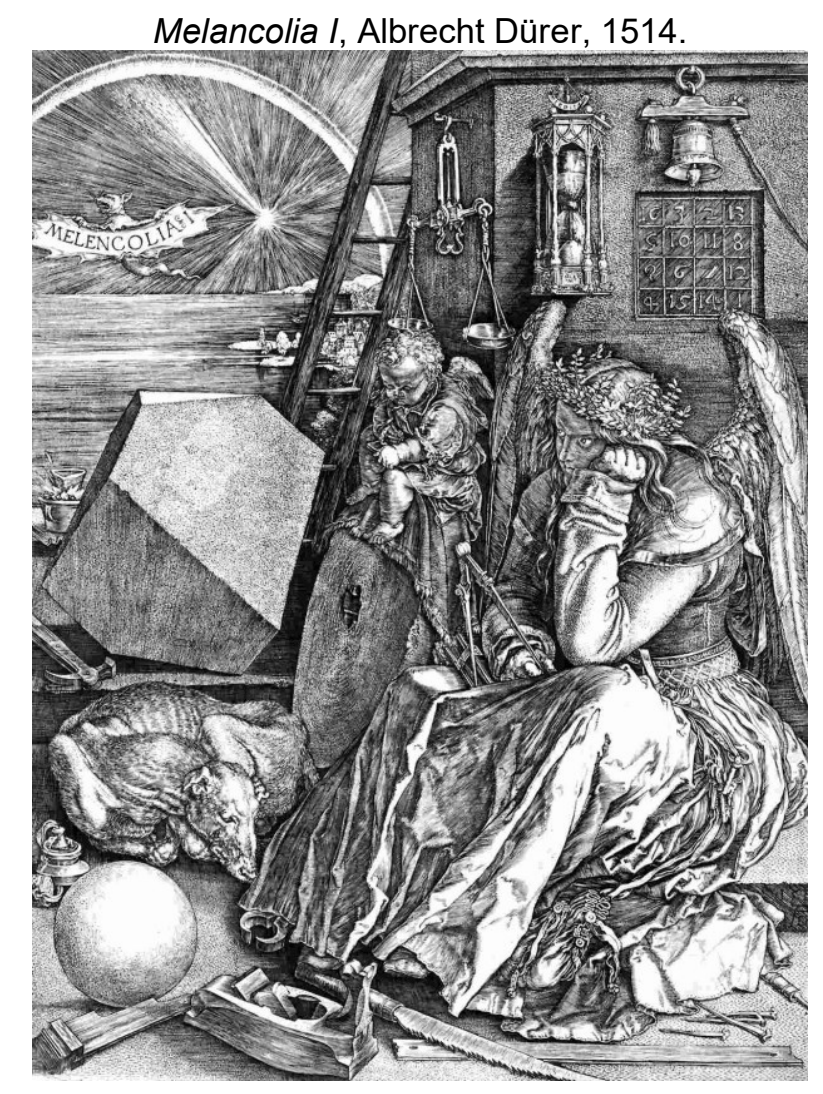

Há algo naquilo que se vê - os objetos de mensuração do mundo, a punição do sátiro pelo coroado Apolo - que se mostra como ruína e que fala sobre o que resiste à própria fala, ou, então, o que resiste à voz, a mudez. As palavras através das quais conhecemos as coisas (e o mesmo poderíamos dizer sobre as imagens através das quais as coisas se oferecem à visibilidade) pressagiam uma tristeza, uma tristeza que emudece (BENJAMIN, 2011, p. 70-71). Não é de qualquer tristeza 
que fala Benjamin, seja na sua reflexão sobre a linguagem, seja no trabalho sobre o drama barroco alemão, mas especificamente do luto. Se as palavras através das quais conhecemos as coisas não são as próprias coisas, e se não é possível conhecê-las senão pelas palavras, todo "conhecer" atualiza uma "incognoscibilidade", uma perda, que demanda um luto. "Assim, aquilo que é triste sente-se conhecido de parte a parte pelo incognoscível" (BENJAMIN, 2011, p. 71).

O problema dessa perda é que aquilo que é perdido não pode ser restaurado - ele não "foi" perdido em um passado remoto, mas corresponde à condição linguística do "mundo" humano. Assim, se trata de uma tristeza pela própria condição humana, uma tristeza que tem na "culpa" seu afeto estruturante, na medida em que se insiste em encontrar "nas coisas" seus "significados". Enquanto a "linguagem de Deus" é uma linguagem nomeadora e criativa - o nome cria a própria coisa -, à "linguagem humana" cumpre estar cindida em relação à "linguagem das coisas": ela conhece somente na medida em que submete as coisas a uma mudez inelutável. O "incomunicável" do luto - aquilo que, traumático, escapa à simbolização, mantendo-se como mudez - não há de encontrar "tradução" resolutiva, pois trata-se, sempre, de "metamorfoses" (BENJAMIN, 2011, p. 64-66): de deslocamentos e condensações. O trabalho de elaboração do luto que não pretenda simplesmente dar à perda uma nova imagem ou objeto, ou seja, que não atualize a culpa, tomaria direção contrária: a do encontro com o precário da palavra, com o impossível do significado.

Se a "pose saturnina do melancólico" sinaliza o luto, ela não fala tanto sobre o seu "lugar" na cena, diante do que seria o "tema", mas, sobretudo, da sua "posição", esta que sustenta seu "olhar". O olhar, direcionado ao lamento, direcionado à impotência, não tem em mira a impotência daquilo que vê, mas, necessariamente espelhando-se naquela, a sua própria. Pois que a impotência "no olhar" do Anjo da História é o da "sua" impossibilidade de "acordar os mortos" 5 . Se o fizesse, poderíamos conjecturar, se sacudisse os ombros dos mortos com suas mãos, em

\footnotetext{
${ }^{5} \mathrm{Em}$ Sobre o conceito de História, Benjamin recorre a outro anjo, desta vez ao de Paul Klee (Angelus Novus), que "parece querer afastar-se de algo que ele encara fixamente". Tal anjo, de olhos "escancarados", seria "o anjo da história". "Seu rosto está dirigido para o passado. Onde nós vemos uma cadeia de acontecimentos, ele vê uma catástrofe única, que acumula incansavelmente ruína sobre ruína e as dispersa a nossos pés. Ele gostaria de deter-se para acordar os mortos e juntar os fragmentos. Mas uma tempestade sopra do paraíso e prende-se em suas asas com tanta força que ele não pode mais fechá-las" (BENJAMIN, 1994, p. 226).
} 
vez de acordá-los, talvez os petrificasse de vez: como num "toque de Midas", os mortos seriam transformados em ouro, em mercadorias, ora, em objetos de fetiche. O que esse olhar "barroco", o olhar do artista, tem como alvo é uma opacidade naquilo que se vê - algo que, nos termos de Didi-Huberman (2010), olha de volta ao artista: o inelutável.

\section{3.}

Nas teses Sobre o conceito de história, Benjamin (1994) nos convida a observar a história desde a perspectiva da "vinda" do Messias, que ele associa à revolução. A potência "teológica" do materialismo histórico seria evidenciada se desfeita a noção de tempo histórico como linearidade, que teria a revolução como "fim". Em seu lugar, a "perspectiva messiânica" permitira compreender a revolução como "meio", como quebra no próprio tempo. Dissociar "fim" de "finalidade" seria o modo de desvelar o próprio tempo como potência, já que o tempo como linearidade e causalidade, que teria como "alvo" a revolução porvir, estaria submetido à "necessidade". Da perspectiva da vinda do Messias, ou seja, da perspectiva da revolução, o passado, e o próprio mundo, se mostram como ruína. No aforismo chamado Final, de Minima Moralia, Adorno (2008, p. 245) assim descreveu o que seria como que a "tarefa" do pensamento crítico: "[...] construir perspectivas em que o mundo se ponha, alheado, com suas fissuras e fendas à mostra tal como alguma vez se exporá indigente e desfigurado à luz messiânica".

Em A ideia de juízo final, Agamben parece dar um passo radical em direção à definição do que seria o trabalho do pensamento, alcançando seu ponto de culminância: a crítica "sobre" a linguagem. Outro modo de dizer que uma crítica deve ser, necessariamente, autocrítica; ou tomar como "fim", ou "alvo", a si mesma, seu próprio "meio": qualquer juízo "na" linguagem sugere proceder de outro lugar, ou instância, que não a própria linguagem. O juízo "final" é aquele que a linguagem faz sobre a própria linguagem: "O poder da linguagem deve voltar-se contra a própria linguagem. O olho deve ver o seu ponto cego" (AGAMBEN, 2012, p. 95). 


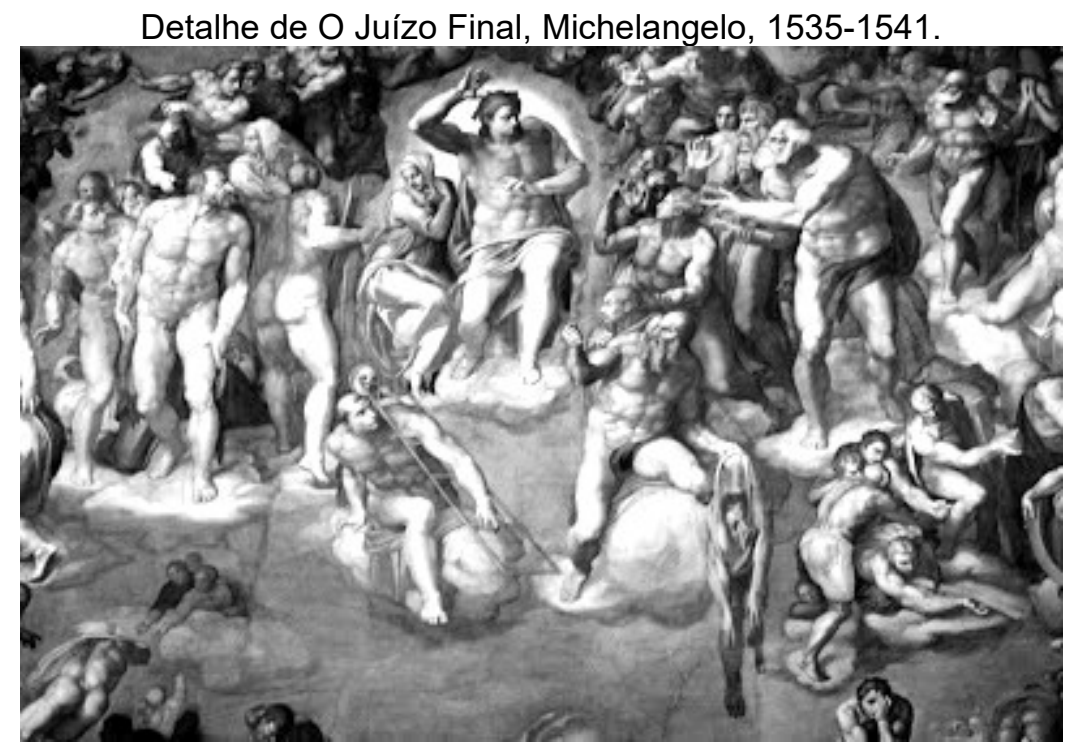

Colhendo tais indicações, talvez possamos lançar uma leitura sobre o motivo de Agamben ter associado o autorretrato de Ticiano, como Midas, ao autorretrato de Michelangelo, como São Bartolomeu, no afresco $O$ juízo final. Neste, Michelangelo/São Bartolomeu está ao lado do Messias (que, sendo católico, diferente do de Benjamin, "retorna"), segurando sua própria pele. Se, à luz messiânica, o "fim" é o "meio" e o mundo está, "indigente e desfigurado", com suas fendas à mostra; se, no juízo final, "o olho deve ver seu ponto cego", o artista, então, põe a si mesmo como matéria de representação, mas um si mesmo como cindido, no corpo de um outro, entre a santidade e a animalidade, entre a salvação e a destruição. É esse "entre" que, à luz messiânica, aparece como um "resto" - o hiato que une e separa potência e impotência (AGAMBEN, 2014). Mas ele "aparece" sem imagem possível, pois trata-se do ponto cego do olho que se volta a si mesmo. Somente pode "aparecer", num instante de perigo, como um lampejo, como um rastro.

O lamento de Marsias, que no artigo de Agamben (2018, p. 15) aparece traduzido como "Por que me esfola?", poderia encontrar outras palavras: "Por que me arrancas a mim mesmo?" (Cf. CERQUEIRA, 2012, p. 70). Não é um suplício ou um pedido de clemência, portanto, o que representa o lamento: ele fala sobre sua própria cisão, sobre o que não tem palavra na palavra, ou o que permanece "cego" ao olhar que busca seu próprio olho. Isso porque a cisão do sujeito é, para Agamben, a que reside na contradição insuperável da voz em relação ao ruído - ou, 
no caso específico de Apolo e de Marsias, entre o logos e o sopro. Ele está cindido pela potência que, não podendo deixar de ser impotência, o habita como ambivalência e descentramento. Se a "inspiração" do artista reside na "sua própria" divisão enquanto sujeito é porque o que é "seu" é experimentado como "resto", ou como "limite", de si em relação a um "si mesmo" que escapa: entre o próprio e o impróprio. Dizendo de outro modo: é porque o gesto da criação é o de se apropriar da "sua" impropriedade. ${ }^{6}$

De uma íntima impropriedade é a relação que o humano tem com a linguagem. Ser do logos não é, todavia, seu senhor. Como Benjamin (2011) insistiu, para o homem a linguagem não é Mittel, meio para um fim, mas Medium, "meio" como condição e cerne, sem relação com uma finalidade exterior e causal. "Na" linguagem, o humano somente pode conhecer o mundo por ela; sem "nomear" os objetos, não há sequer objetos. Mas o "nome" pelo qual invoca a presença das coisas não é o nome próprio das coisas, e, assim, toda nomeação atualiza uma mudez, um vazio de sentido, de luto impossível. Esse vazio, vazio de um "próprio", sendo, no "lamento", a impotência da linguagem, "contém quase que apenas o suspiro sensível" (BENJAMIN, 2011, p. 70).

De acordo com Furio Jesi (2018), em "quase que apenas o suspiro sensível” trata-se de um silêncio que resiste ao significado. Não qualquer silenciar, não um "não dizer" que, na ausência de som, comunica algo, mas uma suspensão do próprio significar. Ou, de modo mais direto: um silêncio, suspiro sensível, que não comunica, e que expõe o vazio inelutável que subjaz na palavra, a própria incomunicabilidade. Que o "suspiro" seja, pois, um "sopro", então devemos lembrar a resposta de Apolo ao lamento de Marsias, dizendo que "não usou nada mais do que aquilo que o adversário havia feito 'ao soprar a flauta'". Pois que foi um "sopro" o gesto da criação do homem por Deus. Depois de "nomear" e, assim, "criar" o mundo, "Deus insuflou no homem o sopro: que é, ao mesmo tempo, vida e espírito e linguagem" (BENJAMIN, 2011, p. 60). Desde sua criação, então, o homem tem com as coisas do mundo uma relação imaterial cujo "símbolo é o som" (BENJAMIN, 2011, p. 60).

"Em O que resta de Auschwitz, Agamben escreveu que o gesto de "poder seu próprio poder-não" é o
que "dá sentido ao ato ou à palavra do auctor" (AGAMBEN, 2008, p. 151), e, em A comunidade que
vem, que a escrita "não provém de uma potência de escrever, mas de uma impotência que se volta
para si mesma" (AGAMGEN, 2013, p. 41). De modo aproximado, Vladimir Safatle, em O circuito dos
afetos, nos diz que "talvez a única função real da arte seja exatamente esta, nos fazer passar da
impotência ao impossível" (SAFALTE, 2016, p. 35).

Ano 6, p. 10-24, 2019. 
Ao contrário das demais coisas no mundo, o homem não tem nome próprio, ou seja, ele não é efeito de uma nomeação criadora, mas, antes, de um "sopro", e, assim sendo, poderíamos perguntar se não é a tal imaterialidade - cujo símbolo é o som - que a violência apolínea se dirige. O som/sopro da música de Marsias, não indo encontrar lugar na palavra, sinaliza à "abertura" da palavra à sua ausência de significado, à "presença" divina no humano que é, ao mesmo tempo, um abandono: fadado a viver "na" linguagem, o homem está destinado a significar sem encontrar significado. A crueldade de Apolo se dirigiria, então, não ao traço animal no sátiro, que seria incapaz de suportar em si mesmo, mas, ao contrário, ao seu caráter "demasiado" humano. Assim, a "cena" da inspiração artística seria a da linguagem que volta seu "poder" sobre a própria linguagem. É a cisão "no" próprio logos - o ponto cego que, no "meio", visa o juízo "final" - que o artista contempla como ruína; e é o conhecimento desta tragédia que ele pretende, pelo olhar, salvar.

4.

O "tema" da última obra de Ticiano é, como sugere Agamben, a própria criação artística, a relação do artista com a inspiração, então representada pelo autorretrato de Ticiano como Midas, que observa (e busca ouvir) atentamente o lamento de Marsias. Em questão não está propriamente o "lugar" dos personagens, mas suas posições e gestos representados. Irrepresentável é, contudo, aquilo que tais posições e gestos sustentam e sugerem: o olhar.

O alvo do olhar é o lamento, e "lamento" é a palavra pela qual se chama à presença aquilo que somente se "presentifica" mediante sua ausência: o inelutável de uma perda, a mudez no nome, a precariedade da significação, o "puro" sopro que penetra sorrateiramente a voz lhe dando "corpo". Som, palavra e visibilidade se deslocam em metáforas incessantes, e por isso o "olhar", que não se confunde com o mero "ver", é a metáfora "exemplar" da relação do artista com a inspiração. Todavia, tanto quanto o olhar, o seu alvo é irrepresentável - o que, pressuposto em um aparecer, não aparece. O alvo do olhar é o seu "ponto cego", sua impossibilidade.

Se o artista aparece, na obra, em uma "pose saturniana" é porque aquilo que ele quer salvar é o que ele tem, ao mesmo tempo, diante de si e em si mesmo, a 
"inspiração", ou seja, o dobrar-se sobre si mesmo da linguagem. Deste modo, a inspiração artística não é a redenção e seu objetivo não é salvar a si mesmo, mas, ao contrário, em flagelo, oferecer-se em sacrifício. Trata-se de uma salvação impossível se aquilo que se quer salvar é, justamente, o impossível. Outro modo de dizer que o artista é aquele que leva às "últimas" consequências o trabalho do pensamento, que, como juízo "final", diz Agamben (2012, p. 95), "virá no fim dos tempos". O "fim" do tempo, que nas teses de Benjamin é o "fim" - interrupção no "meio" - da história, e que no aforismo "Final", de Adorno, é a revelação das "fissuras e fendas" do mundo, em Agamben é o movimento de cisão no "meio" da linguagem.

Se não é a redenção o que busca o pensamento, se não é salvar uma integridade ou uma aparência pela própria aparência (ou, se não é salvar a potência da sua impotência), para apaziguar, na culpa, significante e significado, então este movimento vai radicalmente de encontro com o que seria uma terapêutica: sua "função" não é a de reparar uma catástrofe, não é a de "fetichizar" os mortos, não é a de docilizar o trauma. Se o trabalho do pensamento é como um trabalho de luto, sua elaboração é sempre incompleta pois há de se avir com o "irreparável" - e é sobre ele que fala a voz impossível do lamento.

Neste sentido, deve dizer algo, ao menos à guisa de nota, que pela palavra "lamento" seja possível nomear o canto de abertura de uma capoeira. No "lamento", “o grande momento trágico" da capoeira (CASTRO, 2007, p. 105), não há jogo: o mestre realiza uma espécie de prece, dando lugar a uma "outra voz" (CASTRO, 2007, p. 112) que, amiúde, rememora o passado cativo". Depois da "ladainha", é cantado o refrão, ou o "corrido", e, então, os corpos se põem a jogar. Mas, antes, enquanto a voz do mestre dá suporte ao lamento, o gesto corporal do capoeirista não é outro que de uma atenção, uma "contemplação absorta", como quem dá ouvidos a "uma sabedoria misteriosa". No centro da roda, o capoeirista aguarda o momento da ação, com seu tórax arqueado, o cotovelo em direção ao joelho.

\footnotetext{
7Embora seja possível tratar "lamento" e "ladainha" como sinônimos, de acordo com Maurício Barros de Castro (2007) o "lamento" é a fala de uma "outra voz" que constitui a "ladainha", esta enquanto abertura do jogo (que antecede ao jogo, propriamente dito). "Outra voz" cujo som pode encobrir "a voz original", advindo "das entranhas do corpo" (CASTRO, 2007, p. 112). Se um lamento não se referir, especificamente, ao passado cativo, ele falará, via de regra, ou do presente de segregação e violência ou (e/ou) da história da própria capoeira. De um modo ou de outro, impossível é separar, no presente do canto, o que é perda, o que é violência (de Estado, étnica, etc.) do que é a presença insistente do passado cativo.
} 
Ilustração de Carybé, 1968.

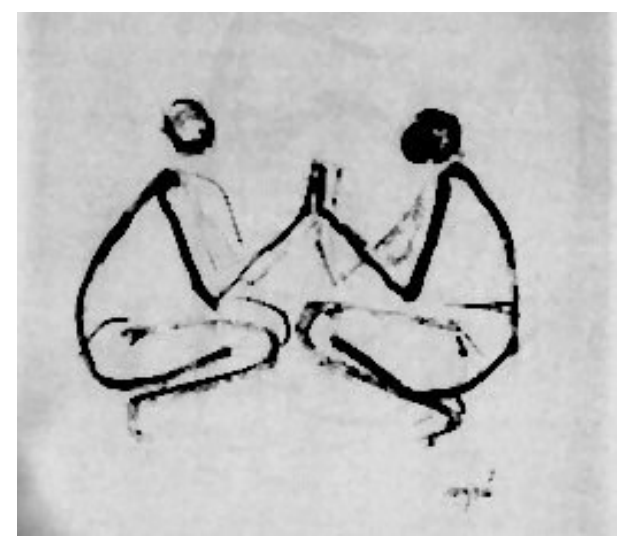

Capoeira, Pierre Verger, 1946-1948.

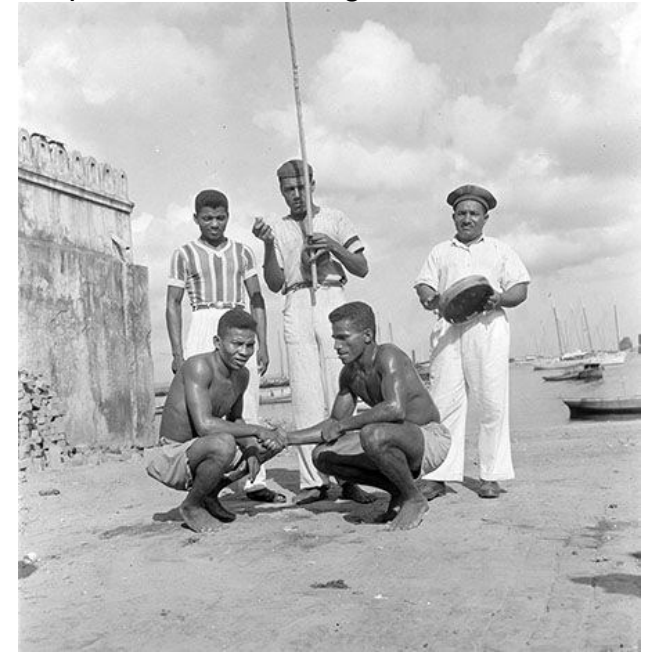

Cumpre observar que o lamento e a ladainha digam respeito a uma capoeira muito específica: a Angola. $\mathrm{O}$ que distingue, fundamentalmente, a capoeira Angola das demais é sua melancolia, ancorada não somente no lamento de abertura, mas, sobretudo, no ritmo e no toque dos instrumentos. A cadência lenta e "arrastada" do toque é como que uma continuação, pela música, do próprio lamento. O passado que não "passa" - da escravidão se desloca do canto ao toque, e do toque ao gesto: ele é incorporado, transformado em gesto (incorporado em uma relação com um "outro" que lhe é espelho, como é possível ver nas imagens de Carybé e de Verger), e não superado. A partir do momento em que cessa a ladainha e começa o jogo, todo gesto do "angoleiro" é de um levante; se o corpo assumir, novamente, a "pose" de um arco, não será mais para contemplar e meditar sobre aquele saber, mas para combater.

Uma pequena ironia satírica, por assim dizer, dos cantos na capoeira reside no fato de que, não raro, se utilizem onomatopeias, e uma muito específica deve chamar atenção: o "zum zum zum"8. Nem palavra nem puro sopro, nem voz nem mero ruído, o "zum zum zum" tem sentido lá onde o logos é impotente. No uso comum, "zum zum zum" se diz quando há confusão, quando há desentendidos,

\footnotetext{
${ }^{8}$ De acordo com Roberta Rosa Portugal (2017), "zum zum", de origem banto, teria no Quicongo acepção assemelhada a do uso comum atual, qual seja, "fazer barulho" (daí sua extensão à "confusão", já que barulho não seria outra coisa que um tipo de confusão sonora). Todavia, cumpriria atentar à definição oferecida pelo compositor de músicas "axé", Mateus Aleluia, como "sonoridade que prende, contemplação de uma ideia" (Cf. GONSALES, 2017). Outras conexões importantes devem incidir, também, no uso do "zum zum zum", ao menos mais duas: a correspondência ao nome de Zumbi e a referência ao Mestre Besouro Mangangá.
} 
quando a "superioridade" do diálogo não é capaz de reparar os conflitos. Pois é o conflito, ele mesmo, que, irreparável, tomar lugar num som que é, ao mesmo tempo, o aparecer do sopro e da voz: não é possível apaziguar, pelo significado, pela racionalidade, a bestialidade da escravidão. Na capoeira Angola, cuja abertura é a ladainha, ou seja, o trabalho do luto, o que se tem é um processo interminável de elaboração - de encontro, não apaziguador, com o irreparável.

\section{REFERÊNCIAS}

ADORNO, Theodor W. Minima moralia. Rio de Janeiro: Azougue, 2008. 1985. ; HORKHEIMER, Max. Dialética do esclarecimento. Rio de Janeiro: Zahar,

AGAMBEN, Giorgio. A comunidade que vem. Belo Horizonte: Autêntica, 2013.

A ideia de prosa. Belo Horizonte: Autêntica, 2012.

A potência do pensamento. Belo Horizonte: Autêntica, 2015.

. O esfolamento de Marsias. Revista Diálogos Mediterrânicos, Universidade Federal do Paraná, n. 14, p. 12-15, jun. 2018.

. O que resta de Auschwitz. São Paulo: Boitempo, 2008.

. O tempo que resta. Belo Horizonte: Autêntica, 2014.

BENJAMIN, Walter. Escritos sobre mito e linguagem. São Paulo: Duas cidades; Ed. 34, 2011.

. Magia e técnica, arte e política. São Paulo: Brasiliense, 1994.

Origem do drama trágico alemão. Belo Horizonte: Autêntica, 2013.

CANTINHO, Maria João. O Anjo Melancólico. Lisboa: Nota de Rodapé, 2015.

CASTRO, Maurício Barros de. Na roda do mundo. 2007. 227 f. Tese (Doutorado) Universidade de São Paulo. São Paulo, 2007.

CERQUEIRA, Fábio Vergara. Apolo e Mársias: certame ou duelo musical? Revista Clássica, Sociedade Brasileira de Estudos Clássicos, v. 25, n. 1/2, p. 61-78, 2012.

DIDI-HUBERMAN, Georges. O que vemos, o que nos olha. São Paulo: Ed. 34, 2010. 
GONSALES, Fernando. Entenda 'te bandê', 'te curupaco', 'maimbê' e outros mistérios do axé. Folha de São Paulo, São Paulo, 02 fev. 2017.

JESI, Furio. O texto como versão interlinear do comentário. Revista Diálogos Mediterrânicos, Universidade Federal do Paraná, n. 14, p. 16-20, jun. 2018.

PORTUGAL, Roberta Rosa. O samba-reggae: uma afirmação do sagrado, cultural e político. Odeere, Vitória da Conquista, n. 3, v. 3, p. 299-322, 2017.

SAFATLE, Vladimir. O circuito dos afetos. Belo Horizonte: Autêntica, 2016.

Artigo recebido em: 12/09/2018

Artigo aprovado em: 12/11/2018

Artigo publicado em: 04/02/2019 